\title{
Studies on the Alkaloid Contents of the Bark of Cinchona Found in Sri Lanka
}

\author{
L. A. Goonetillake, L. S. R. Arambewela and R. DE Costa \\ Natural Products Section, Ceylon Institute of Scientific and Industrial Research, Colombo 7, \\ Sri Lanka
}

(Date of receipt: 8 July 1982)

(Date of acceptance: 24 May 1984)

\begin{abstract}
Studies on Cinchona carried out in our laboratory indicated that the extraction of bark with benzene - ethanol $(1: 1)$ mixture gave the highest yield of alkaloids. The optimum time of extraction required to obtain the maximum content of alkaloids was found to be 16 hours. The survey of existing Cinchona trees in the country indicated that quite a large number of trees are still existing in the jungles of the tea estates in a neglected state. The alkaloid contents of the samples collected from these plants varied very widely, the highest alkaloid contents were found in plants growing in high elevations. The two dimensional thin layer chromatographic technique devised in our laboratory was used to study the distribution of alkaloids in the bark samples.
\end{abstract}

The genus Cinchona belongs to family Rubiaceae and thrives best in tropical climates at altitudes of 1000 to $2000 \mathrm{~m}$. The most common Cinchona species (in Sri Lanka) yielding commercially important bark are Cinchona succirubra and Cinchona ledgeriana. Over twenty. alkaloids are reported to be present in Cinchona bark out of which quinine and quinidine are the commercially important ones. Quinine had been used as an antimalarial drug while at present it is widely used as a flavouring agent in soft drinks. Quinidine is being used as a cardiac depressant.

Sri Lanka has been associated with Cinchona industry since $1858.2^{2} \%$ In 1886 this country supplied almost $3 / 4$ of the world bark requirements. ${ }^{2}$ From this time onwards the export was on the decline but continued in a small scale until 1976. Though Cinchona plantations in Sri Lanka have been completely neglected still there are some trees remaining in tea estates and forests. This study was undertaken as the interest in Cinchona has revived during recent times.

\section{Demonstration of distribution of alkaloids}

This was performed using two dimensional tlc method which we devised earlier.? This technique is capable of separating the Cinchona alkaloids into over 14 components. 
Improvements in the extraction of alkaloids in the laboratory

The extraction of alkaloids of Cinchona bark was carried out according to the method given in Modern Methods of Plant Analysis. ${ }^{3}$ In order to attempt to increase the yields of alkaloids the extraction was carried out using several solvents such as ethanol, chloroform, methanol, petroleum ether, ethanol-benzene (1:1) mixture methanol-benzene mixture $(1: 1)$ and ethanol-petroleum ether $(1: 1)$ mixture.

$20 \mathrm{gms}$ of dried powdered bark are used in each experiment and the averages of three readings were taken. The results of the extractions are given in Table 1.

TABLE 1. Effect of solvent on extraction of quinine from cinchona bark

\begin{tabular}{lc}
\hline Solvent & $\begin{array}{c}\text { Quinine as quinine } \\
\text { sulphate } 2 \mathrm{H}_{\mathrm{g}} \mathrm{O}(\%)\end{array}$ \\
\hline Benzenc & 3.72 \\
Ethanol & 4.52 \\
Chloroform & 4.20 \\
Methanol & 3.80 \\
Petroleum ether & 0.68 \\
Ethanol : Benzene & 5.25 \\
Methanol: Benzene & 4.28 \\
Ethanol : Petroleum etc & 3.20 \\
\hline
\end{tabular}

The extraction of alkaloids using benzene-ethanol solution as the solvent was carried out for varying periods of time and the quinine contents of each extract was determined.

\section{Survey of the cinchona trees}

This study was carried out at the Tea Research Institute and Department of Minor Exports Crops were interested in the replanting of cinchona. The aim of this survey was: (i) to determine the most suitable geographical location for cinchona trees, (ii) to select best trees to obtain planting material for future propagation and (iii) to obtain a rough estimate of the number of trees still remaining in the country. In this survey 101 samples of cinchona bark collected from trees in different areas were examined for quinine content and total alkaloid contents. The distribution of alkaloids of each sample was determined by monitoring on tlc plates. ${ }^{9}$ The results of the analysis are given in Table 2. 
TABLE 2. Summary of quinine and total alkaloid contents of the cinchona bark samples analysed

\begin{tabular}{|c|c|c|c|c|c|}
\hline \multirow{2}{*}{ Location } & \multirow{2}{*}{$\begin{array}{l}\text { No. of samples } \\
\text { collected }\end{array}$} & \multirow{2}{*}{\multicolumn{2}{|c|}{$\begin{array}{l}\text { Quinine content estimated } \\
\text { as quinine sulphate } 2 \mathrm{H}_{2} \mathrm{O}\end{array}$}} & \multicolumn{2}{|c|}{ Total alkaloid } \\
\hline & & & & $(\%)$ & mean \\
\hline 1. Udagama & 4 & $3.5-5.5$ & 4.1 & & \\
\hline $\begin{array}{l}\text { 2. Hunnasgiriya } \\
(1656 \mathrm{~m})\end{array}$ & 6 & $2.6 .-8.5$ & 5.1 & $7.5-11.3$ & 8.6 \\
\hline $\begin{array}{l}\text { 3. Nuwara Eliya } \\
(2000-2330 \mathrm{~m})\end{array}$ & 10 & $1.2-10.1$ & 6.1 & $5.1-11.9$ & 9.4 \\
\hline $\begin{array}{l}\text { 4. Talawakele } \\
(1400 \mathrm{~m})\end{array}$ & 35 & $3.2-9.6$ & 6.0 & $3.9-12.7$ & 8.9 \\
\hline $\begin{array}{l}\text { 5. Boralanda } \\
(1266 \mathrm{~m})\end{array}$ & 16 & $5.2-10.5$ & 7.6 & $6.5-15.8$ & 11.4 \\
\hline $\begin{array}{l}\text { 6. Dambetenna } \\
(1334-2000 \mathrm{~m})\end{array}$ & 4 & $6.6-10.2$ & 8.5 & $10.3-17.2$ & 11.5 \\
\hline $\begin{array}{l}\text { 7. Belihuloya } \\
(1000-1830 \mathrm{~m})\end{array}$ & 26 & $1.1-9.7$ & 6.7 & $3.3-14$ & 9.6 \\
\hline
\end{tabular}

The experiments that were conducted to improve the yields of extraction of quinine indicated that benzene-ethanol mixture was the best. Ethanol, chloroform and methanol-benzene mixtures gave higher yields than benzene. However ethanol-benzene mixtures cannot be used for large scale extractions due to carcinogenic properties of benzene. For laboratory extractions the benzene-ethanol mixture was selected as it gave the highest yield.

The experiments carried out in order to determine the optimum time required for the extraction of most of the Cinchona alkaloids indicated that highest yields were obtained in 16-18 hours of extractions.

These studies showed that considerable care has to be exercised if the correct yield and alkaloid content of a Cinchona samples are to be obtained, both solvents and extraction time being important factors.

The survey of the Cinchona trees still remaining in Sri Lanka, for their quinine and total alkaloid contents yielded interesting results. The samples collected from Tea Research Institute were obtained from branches of $2 \frac{1}{2}-4$-year old trees while the other samples were obtained from old trees in the jungles whose ages were not known. Although alkaloid contents cannot be related to the variety of plant due to extensive hybridisation there exists some relationship between the alkaloid contents and elevations. The highest alkaloid contents were observed in trees growing between 1000-2500 m. Although there were marked variations between trees in these locations it was possible to select trees where quinine and total alkaloid contents were more than 9 and $14 \frac{1}{2} \%$ respectively. 
The fairly high content of quinine in the samples obtained from the branches of young Cinchona trees in Talawakele was another interesting feature.

The study of the distribution of alkaloids in the total alkaloid extract of the samples was carried out employing the thin layer chromatographic technique devised in our laboratory. ${ }^{9}$ This study indicated that the major alkaloid in Ledgeriana type of trees (this leaf types) was quinine while in broad leaf types of trees cinchonidine was present to the same extent or more than quinine on visual examination.

Our study also indicated that a large number of Cinchona trees were remaining scattered and neglected in the jungles of the tea estates. Some of these trees are being used as firewood as few persons in the estates know the identity and the value of this plant. A reasonable income can be obtained if steps are taken to locate these existing plants, maintain infrastructure and harvest the bark carefully. Some attempts should also to be taken under crops diversification scheme to plant Cinchona in the vast areas of land that are unsuitable for tea in such estates.

\section{Acknowledgements}

This work has been supported by grants from Minor Exports Crops Department and the Natural Resources, Energy and Science Authority of Sri Lanka. Thanks are also due to Dr E. R. Jansz for his interest in this work.

\section{References}

1. Adamski, R. \& Bitner, J. (1968). Farm. Polska, 24: 17.

2. Ameer Ali, A. C. L. (1974). Modern Ceylon Studies 5 (1); 93.

3. CrOMwell, B. T. (1955). In modern methods of plant analysis Vol. 4 pp. 400 Springer Verlag Berlin.

4. Hartel, G. \& Fluck, H. (1968). Pharm. Acta. Helv. 39: 294.

5. JaYAWEera, D. M. A. (1943). Trop. Agriculturist, 99: 91-95.

6. Suszko - Purzycka, A. \& TrzeBny, W. (1964). J. chromatogr. 16: 239.

7. Suszko - Purzycka, A. \& TrZebny, W. (1965). J. chromatogr. 17: 114.

8. Von Oswald, N. \& Fluck, H. (1964). Pharm. Acia. Helv. 39: 294.

9. Wijesekera, R. O. B., Rajapakse, L. S. \& Chelvaratnam, D. W. (1976). Journal of Chromatography 121: 388-389. 